\title{
Belowground hydraulic conductance in a mature boreal Scots
} pine tree

\section{Lintunen, Anna}

2018

Lintunen , A , Paljakka , T , Salmon , Y \& Hölttä , T 2018 , ' Belowground hydraulic conductance in a mature boreal Scots pine tree ' , Acta Horticulturae , vol. 2018 , no. 1222 , pp. 103-108 . https://doi.org/10.17660/ActaHortic.2018.1222.14

http://hdl.handle.net/10138/307166

https://doi.org/10.17660/ActaHortic.2018.1222.14

unspecified

acceptedVersion

Downloaded from Helda, University of Helsinki institutional repository.

This is an electronic reprint of the original article.

This reprint may differ from the original in pagination and typographic detail.

Please cite the original version. 


\title{
Belowground hydraulic conductance in a mature boreal Scots pine tree
}

\author{
Anna Lintunen ${ }^{1,2}$, Teemu Paljakka², Yann Salmon ${ }^{1}$ and Teemu Hölttä2 \\ 1Department of Physics, P.O. Box 68, FI-00014 University of Helsinki, Helsinki, Finland. \\ ${ }^{2}$ Department of Forest Sciences, P.O. Box 27, FI-00014 University of Helsinki, Helsinki, \\ Finland.
}

\begin{abstract}
We studied the dynamics of belowground hydraulic conductance $\left(k_{b g}\right)$ of a mature Scots pine tree in field conditions using continuous xylem diameter change and sap flow measurements over a full growing season in a boreal environment. Our aim was to analyze how $k_{b g}$ is linked to soil temperature and soil water content. $k_{b g}$ was calculated as the ratio of daily maximum sap flow rate to the difference between stem and soil water potential estimated from daily diameter variations of xylem measured with point dendrometers. $k_{b g}$ increased with increasing soil temperature in spring and autumn when soil temperatures were below $+8^{\circ} \mathrm{C} . k_{b g}$ increased also with increasing soil water content if soil temperature was high enough as was the case in summer. The results suggest that $k_{b g}$ in the studied tree was more limited by soil temperature than water content.
\end{abstract}

Keywords: cost of water, hydraulic conductance, Pinus sylvestris, point dendrometer, sap flow

\section{INTRODUCTION}

For plants, water loss and $\mathrm{CO}_{2}$ assimilation are tightly coupled as both occur through the same stomatal pores in leaves. The loss of water from the leaves to the atmosphere is replaced with sap flow from the soil through the xylem transport tissue. Understanding tree water use and water balance is important as photosynthetic production and tree growth are limited by the capacity of trees to extract water from the soil and transport it to leaves. Belowground hydraulic conductance $\left(k_{b g}\right)$ is one of the least understood component of the hydraulic pathway between soil and atmosphere. While $k_{b g}$ has been measured for smaller plants (e.g. Running and Reid, 1980; BassiriRad et al., 1991; Nobel et al., 1990) and tree seedlings of various species in laboratory (e.g. Day et al., 1991; Wan et al. 1999, 2001; Cochard et al., 2000; McLean et al., 2011), it has seldom been measured continuously for mature trees in field conditions (Martínez-Vilalta et al., 2007; McElrone et al., 2007).

Hydraulic conductance is defined as the flow rate per unit pressure driving force, and the driving force in the case of belowground hydraulic conductance is the water potential difference between the stem base and the soil. In the approach introduced by Martínez-Vilalta et al. (2007), $k_{b g}$ was calculated as ratio of area-specific sap flow rate and the difference between soil and stem water potentials estimated from xylem diameter at predawn and during the day, respectively. Xylem and whole stem diameter changes are assumed to correlate linearly with stem water potential changes in steady-state conditions (e.g. Irvine and Grace, 1997; Perämäki et al., 2001; Dietrich et al., 2018).

Root water uptake capacity is known to decrease with decreasing soil water content due to decreased soil hydraulic conductance (e.g. Duursma et al., 2008). In addition to soil water content, soil temperature has been found to play a key role in root water uptake capacity especially at low soil temperatures (e.g. Running and Reid, 1980; Bassirirad et al., 1991; Nobel et al., 1990; Day et al., 1991; Wan et al., 1999, 2001; Cochard et al., 2000). For example, Wan et al. (1999) showed with Populus tremuloides seedlings that root water flow was decreased by decreasing soil temperature from $20^{\circ} \mathrm{C}$ downwards. Decrease in water 
uptake capacity with decreasing temperature cannot be fully explained by increasing water viscosity, but is also due to changes in some other factors such as changes in root metabolism (Wan et al. 2001). In accordance, Cochard et al. (2000) showed with Quercus robur saplings that decreasing soil temperature decreased root conductance considerably, and that this decrease could be explained by changes in water viscosity only in temperatures between 35 and $15^{\circ} \mathrm{C}$; in colder temperatures, the decrease was steeper and was suggested to be due to changes in membrane fluidity.

Especially in temperatures below $7{ }^{\circ} \mathrm{C}$, root hydraulic resistance has been shown to increase exponentially with temperature (Running and Reid, 1980). Possible causes of decreased root conductance in short term are formation of xylem embolism, formation of gels and tyloses, increase in xylem sap viscosity, changes in ionic strength or changes in extraxylary hydraulic conductivity such as aquaporin functioning or changes in turgor pressure (Hacke, 2014). In addition to sap viscosity, we can expect that soil temperature has a strong effect on aquaporin functioning. Aquaporins are channel-forming membrane proteins present in the plasma membranes and they are highly specific for water, thus enabling rapid transmembrane water flow in plants (Johansson et al., 2000; Javot and Maurel, 2002; McLean et al., 2011; Johnson et al., 2014). Water flow via aquaporins is sensitive to temperature in a way that the water channels significantly contribute to water transport only within an optimum temperature region (Murai-Hatano et al., 2008; Ionenko et al., 2010). Physiological activity in general decreases with decreasing temperature (e.g. Way and Oren, 2010), so refilling of xylem embolism and changes in ionic strength might also be affected by temperature.

We studied the dynamics of $k_{b g}$ of a mature Scots pine (Pinus sylvestris L.) tree at SMEAR II station in Finland using continuous stem sap flow and xylem diameter change measurements over a full growing season. Our aim was to analyze how soil temperature and soil water content drive $k_{b g}$ in a mature Scots pine in different seasons.

\section{MATERIAL AND METHODS \\ Study site}

We measured a Scots pine tree in a boreal, evergreen coniferous forest at SMEAR II in Hyytiälä (N 61 $50.8^{\prime}$, E $24^{\circ} 17.7^{\prime}, 180$ m.a.s.l.) in year 2013. The vegetation type is Vaccinium (Cajander, 1926) and the forest floor is dominated by dwarf shrubs and mosses. The soil type is glacial till. Mean annual precipitation is $700 \mathrm{~mm}$ and mean air temperature $+4{ }^{\circ} \mathrm{C}$. The measured tree is 55 years old, $18 \mathrm{~m}$ high and breast height diameter is $19 \mathrm{~cm}$.

\section{Field measurements}

Sap flux density was measured with constant heat dissipation sensor (Granier, 1985). Probe pairs were inserted $4 \mathrm{~cm}$ into the xylem (typical conductive depth of sapwood in mature pine trees in the stand) at breast height $(1.3 \mathrm{~m})$, with a vertical separation of $11 \mathrm{~cm}$, and were covered with reflective aluminum shelter. The sensors were located on the northern side of the stem. Sap flow was recorded in minute frequency. Zero sap flow at night was defined as average of seven consecutive nights as suggested by Lu et al. (2004).

The water potential difference between the stem base and the soil was derived from xylem diameter measurements at breast height; stem water potential was assumed to be proportional to xylem diameter (e.g. Irvine and Grace, 1997; Perämäki et al., 2001; Dietrich et al., 2018) and soil water potential linearly proportional to the highest xylem diameter encountered during the night (Martínez-Vilalta et al., 2007). Xylem diameter was measured continuously with linear displacement transducer point dendrometers (Solartron Inc., Model AX/5-0/5, Bognor Regis, West Sussex, UK; accuracy of $1 \mu \mathrm{m}$ ). In addition, relative air humidity, air temperature, soil temperature and volumetric water content in B1 horizon (9$14 \mathrm{~cm}$ depth) were measured continuously.

Rainy days (defined as days for which the mean of the $10 \%$ lowest values of relative humidity is above $75 \%$ ) and days with freezing events (defined as days for which the mean of the $10 \%$ lowest values of ambient air temperature is below $0^{\circ} \mathrm{C}$ ) were excluded from the analysis. Rainy days were excluded since water uptake directly through the bark can be 
expected to interfere with the interpretation of the xylem diameter change measurements. Days with a minimum temperature below zero were excluded because freezing events affect both diameter change and sap flow measurements.

\section{Calculation of belowground hydraulic conductance}

Belowground hydraulic conductance was calculated as the ratio of daily maximum (mean of the $10 \%$ highest values) of sapwood-specific flow rate to the difference between daily maximum (mean of the 10\% highest values) and daily minimum (mean of the $10 \%$ lowest values) of xylem diameter. We used daily values as time lags caused by hydraulic capacitance likely disturbs analysis on short-term dynamics (Martinez-Vilalta et al., 2007). $K_{b g}$ was normalized with the maximum value and only $k_{b g}$ calculated when soil temperature started to increase from zero, which corresponds to the time of soil thawing. Belowground hydraulic conductance in this study actually includes in addition to the belowground parts, the stem base below the breast height. However, it seems that Scots pines at SMEAR II station experience drought induced embolism only marginally and thus the conductance should remain the same in the stem base as it is in the roots (Hölttä et al., 2005; Sevanto et al., 2005).

\section{Statistical analysis}

First, it was analyzed how soil temperature, season and their interaction variable affect $k_{b g}$. The seasons were defined so that spring begins when snow melts and continues until the daily minimum (mean of the $10 \%$ lowest values) ambient temperature reaches $+8^{\circ} \mathrm{C}$. Then summer follows and continues until the daily minimum ambient temperature drops again below $+8^{\circ} \mathrm{C}$, after which it is the autumn until the air temperature drops to $0{ }^{\circ} \mathrm{C}$. Second, it was analyzed how soil water content, season and their interaction variable affect $k_{b g}$. Third, it was analyzed how soil temperature, soil water content, season and their interaction variables affect $k_{b g}$. The analysis was made with the GLM procedure (SAS Statistical Analysis System) that uses the method of least squares to fit general linear models.

\section{RESULTS AND DISCUSSION}

Time series of $k_{b g}$, soil temperature and soil water content show that after soil temperature increases above zero in the spring, belowground conductance begin to increase and soil water content to decrease towards the summer (Fig. 1). Then in autumn, soil temperature decreases again and soil water content increases, while $k_{b g}$ decreases (Fig. 1).

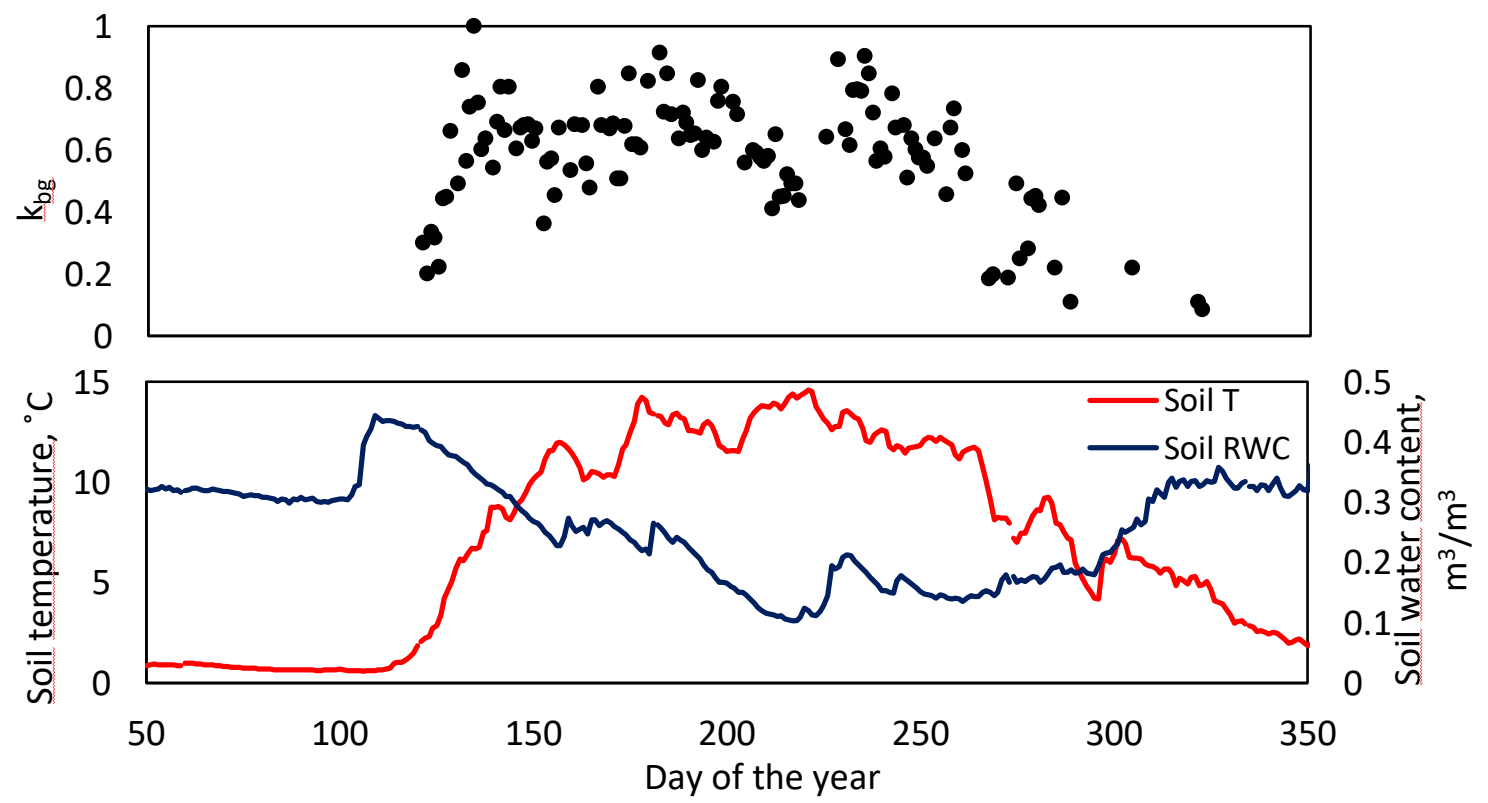

Figure 1. Time series of normalized belowground hydraulic conductance, soil temperature (Soil T) and volumetric soil water content (Soil RWC) in 2013. 
Belowground hydraulic conductance was higher in summer than in spring or autumn, but increased with increasing soil temperature more in spring than in summer or autumn (Fig. 2). $k_{b g}$ increased also with increasing soil water content in summer, but the correlation between $k_{b g}$ and soil water content was negative in spring and autumn (Fig. 3). This is because $k_{b g}$ increased with increasing soil water content only if soil temperature was high enough.

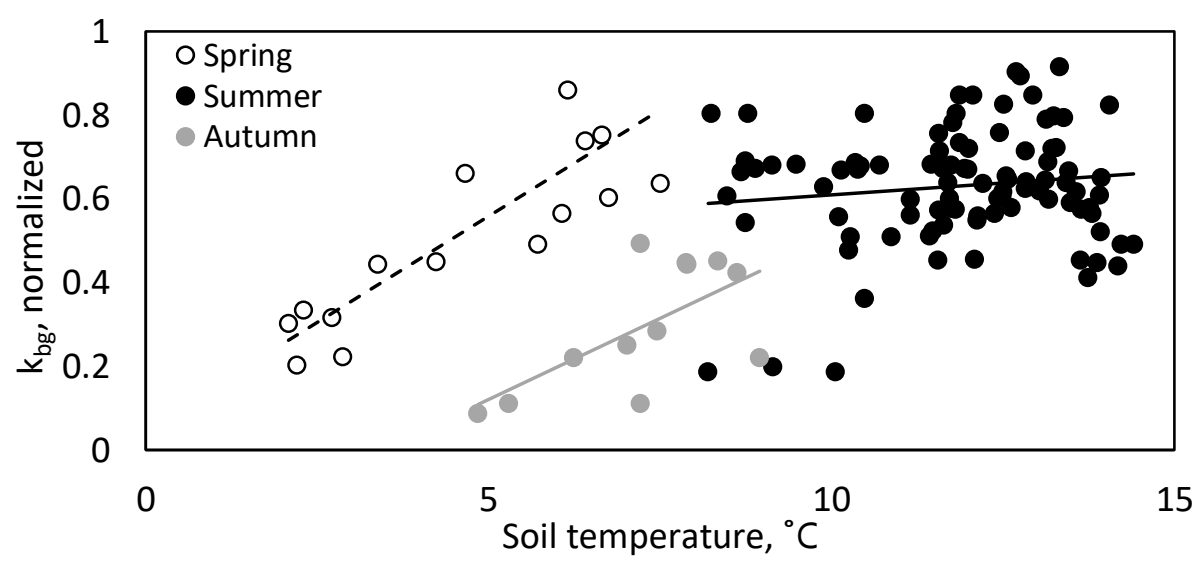

Figure 2. Normalized belowground hydraulic conductance $\left(k_{b g}\right)$ plotted against soil temperature in spring $\left(\mathrm{R}^{2}=0.71, \mathrm{y}=0.10 \mathrm{x}+0.05\right)$, summer $\left(\mathrm{R}^{2}=0.02, \mathrm{y}=0.01 \mathrm{x}+0.50\right)$ and autumn $\left(R^{2}=0.42, y=0.08 x-0.27\right)$. Linear fits are drawn for each season.

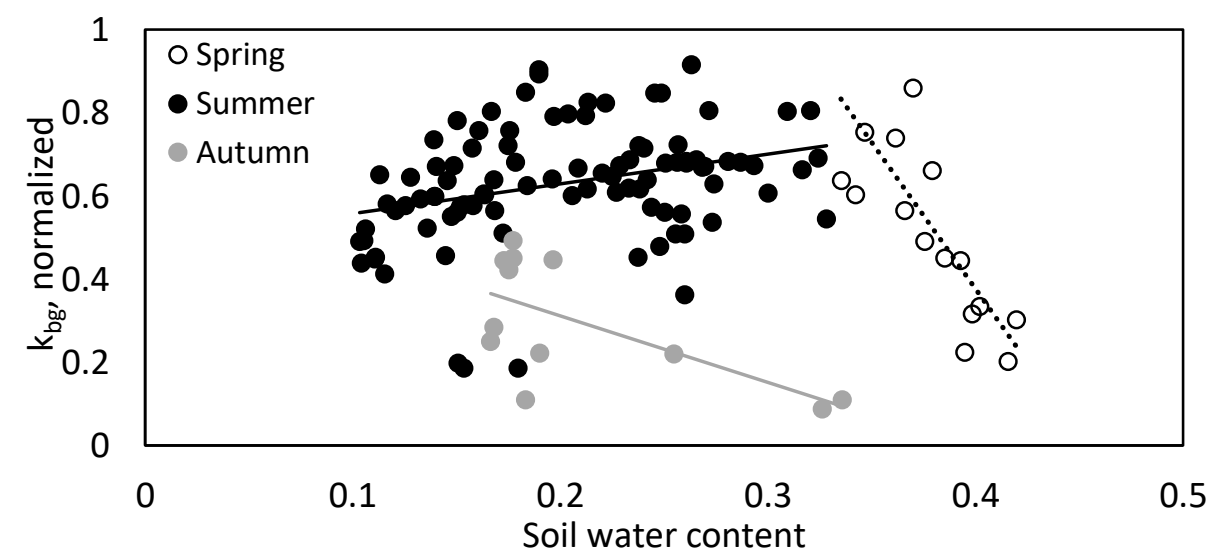

Figure 3. Normalized belowground hydraulic conductance $\left(k_{b g}\right)$ plotted against volumetric soil water content in spring $\left(R^{2}=0.61, y=-7.04 x+3.19\right)$, summer $\left(R^{2}=0.10, y=0.71 x+0.49\right)$ and autumn $\left(R^{2}=0.42, y=-1.60 x+0.63\right)$. Linear fits are drawn for each season.

$k_{b g}$ during spring and autumn was limited by soil temperature, and by soil water content in summer. Especially during spring, the correlation between soil water content and $k_{b g}$ was strongly negative due to cold soil. We also found a steeper decrease of $k_{b g}$ with decreasing soil temperature in spring, when soil temperature is below $+8^{\circ} \mathrm{C}$. Belowground hydraulic conductance is increasing with increasing temperature likely due to decreasing viscosity and increasing aquaporin activity (e.g. Javot and Maurel, 2002). Also new root tips and mycorrhizas grow in spring when soil temperature increases above a certain threshold temperature, and the number of mychorrizas per root length have been shown to increase with increasing soil temperature in the root system of Pinus sylvestris seedlings (Domisch et al. 2002) thus increasing $k_{b g}$.

As soil temperature affects the uptake and transport of water in the roots, soil water content has a strong effect on the accessibility of water for the roots. Soil matric potential and hydraulic conductivity decreases with decreasing soil water content thus leading to decreased root water uptake (Lobet et al., 2014). 
Unlike the present study, Martinez-Vilalta et al. (2007) found no clear relations between $k_{b g}$ and soil temperature or soil water content. However, their data was measured in Scotland from mid-August to November. The climate in Scotland is temperate and oceanic, and their measurements were done in late summer and autumn. The studied coniferous stand was located in boreal environment that can be characterized as cold and moist. Temperature easily dropped below $+5^{\circ} \mathrm{C}$ in spring and autumn, but soil water content did not drop below 0.3 in spring 2013 and never below 0.1 even in summer 2013. Thus both studies together suggests that the scales of soil temperature and soil water content needs to be large enough to induce effect on $k_{b g}$. The limiting factors likely vary depending on the environment, and would most likely be very different in warm and dry climate.

\section{CONCLUSIONS}

It was shown that in the studied mature Scots pine tree, $k_{b g}$ was dependent on soil temperature and water content. Soil temperature was shown to be the limiting factor for $k_{b g}$ in the studied tree during spring and autumn. During summer, soil water content had a positive effect on belowground hydraulic conductance in the absence of low soil temperatures. As this is a pilot study including no repetition on tree individuals, the results should be considered as preliminary results that give direction for further studies.

\section{ACKNOWLEDGEMENTS}

This work was supported by the Academy of Finland grants \#268342, \#284701, \#307331 and \#310375.

\section{Literature cited}

BassiriRad, H., Radin, J. W., \& Matsuda, K. (1991). Temperature-dependent water and ion transport properties of barley and sorghum roots I. Relationship to leaf growth. Plant Physiol. 97(1), 426-432 https://doi.org/10.1104/pp.97.1.426.

Cochard, C., Martin, R., Gross, P., and Bogeat-Triboulot, M.B. (2000). Temperature effects on hydraulic conductance and water relations of Quercus robur L. J. Exp. Bot. 51 (348), 1255-1259 https://doi.org/10.1093/jexbot/51.348.1255.

Day, T.A., Heckathorn, S.A., and DeLucia, E.H. (1991). Limitations of photosynthesis in Pinus taeda L. (loblolly pine) at low soil temperatures. Plant Physiol. 96, 1246-1254 https://doi.org/10.1104/pp.96.4.1246.

Dietrich, L., Zweifel, R., and Kahmen, A. (2018) Daily stem diameter variations can predict the canopy water status of mature temperate trees. Tree Physiol. 00, 1-12 https://doi.org/10.1093/treephys/tpy023

Domisch, T., Finér, L., Lehto, T., and Smolander, A. (2002). Effect of soil temperature on nutrient allocation and mycorrhizas in Scots pine seedlings. Plant Soil 239, 173-185.

Duursma, R.A., Kolari,P., Perämäki,M., Nikinmaa,E., Hari,P., Delzon,S., Loustau, D., Ilvesniemi, H., Pumpanen, J., and Mäkelä, A. (2008). Predicting the decline in daily maximum transpiration rate of two pine stands during drought based on constant minimum leaf water potential and plant hydraulic conductance. Tree Physiol. 28(2), 265-276 https://doi.org/10.1093/treephys/28.2.265.

Hacke, U.G. (2014). Variable plant hydraulic conductance. Tree Physiol. 34, 105-108

https://doi.org/10.1093/treephys/tpu007.

Hölttä, T., Vesala, T., Nikinmaa, E., Perämäki, M., Siivola, E., and Mencuccini, M. (2005) Field measurements of ultrasonic acoustic emissions and stem diameter variations. New insight into the relationship between xylem tensions and embolism. Tree Physiol. 25, 237-243

Ionenko, I.F., Anisimov, A.V., and Dautova, N.R. (2010). Effect of temperature on water transport through aquaporins. Biol. Plant. 54 (3), 488-494 https://doi.org/10.1007/s10535-010-0086-z.

Irvine, J., and Grace, J. (1997). Continuous measurements of water tensions in the xylem of trees based on the elastic properties of wood. Planta 202, 455-461 https://doi.org/10.1007/s004250050149. 
Javot, H., and Maurel, C. (2002). The role of aquaporins in root water uptake. Ann Bot. 90, 301-303 https://doi.org/10.1093/aob/mcf199.

Johansson, I., Karlsson, M., Johanson, U., Larsson, C., and Kjellbom, P. (2000). The role of aquaporins in cellular and whole plant water balance. Biochim. Biophys. Acta 1465, 324-342 https://doi.org/10.1016/S00052736(00)00147-4.

Johnson, D.M., Sherrard, M.E., Domec, J-C., and Jackson, R.B. (2014). Role of aquaporin activity in regulating deep and shallow root hydraulic conductance during extreme drought. Trees $28,1323-1331$ https://doi.org/10.1007/s00468-014-1036-8.

Lu, P., Urban, L., and Zhao, P. (2004). Granier's thermal dissipation probe (TDP) method for measuring sap flow in trees: theory and practice. Acta Bot. Sin. 46(6), 631-646

Martínez-Vilalta, J., Korakaki, E., Vanderklein, D., and Mencuccini, M. (2007). Below-ground hydraulic conductance is a function of environmental conditions and tree size in Scots pine. Funct. Ecol. 21, 1072-1083 https://doi.org/10.1111/j.1365-2435.2007.01332.x.

McElrone, A.J., Bichler, J., Pockman, W.T., Addington, R.N., Linder, C.R., and Jackson, R.B. (2007). Aquaporinmediated changes in hydraulic conductivity of deep tree roots accessed via caves. Plant Cell Environ. 30, 14111421 https://doi.org/10.1111/j.1365-3040.2007.01714.x.

McLean, E.H., Ludwig, M., and Grierson, P.F. (2011). hydraulic conductance and aquaporin abundance respond rapidly to partial root-zone drying events in a riparian Melaleuca species. New Phytol., 192, 664-675 https://doi.org/10.1111/j.1469-8137.2011.03834.x.

Murai-Hatano, M., Kuwagata, T., Sakurai, J., Nonami, H., Ahamed, A., Nagasuga, K., Matsunami, T., Fukushi, K., Maeshima, M., and Okada, M. (2008). Effect of low root temperature on hydraulic conductivity of rice plants and the possible role of aquaporins. Plant Cell Physiol. 49(9), 1294-1305 https://doi.org/10.1093/pcp/pcn104.

Nobel, P.S., Schulte, P.J., and North, G.B. (1990). Water influx characteristics and hydraulic conductivity for roots of Agave deserti engelm.. J Exp Bot 41(4), 409-415. https://doi.org/10.1093/jxb/41.4.409.

Perämäki, M., Nikinmaa, E., Sevanto, S., Ilvesniemi, H., Siivola, E., Hari, P., and Vesala, T. (2001). Tree stem diameter variations and transpiration in Scots pine: an analysis using a dynamic sap flow model. Tree Physiol. 21(12-13), 889-897 https://doi.org/10.1093/treephys/21.12-13.889

Running, S.W., and Reid, C.P. (1980). Soil temperature influences on root resistance of Pinus contorta seedlings. Plant physiol. 65(4), 635-640.

Sevanto, S., Hölttä, T., Markkanen, T., Perämäki, M., Nikinmaa, E. and Vesala, T. (2005) Relationships between diurnal xylem diameter variation and environmental factors in Scots pine. Bor. Environm. Res. 10, 447-458 Wan, X., Landhäusser, S.M., Zwiazek, J.J., and Lieffers, V.J. (1999). Root water flow and growth of aspen (Populus tremuloides) at low root temperatures. Tree Physiol. 19 879-884 https://doi.org/10.1093/treephys/19.13.879

Wan, X,, Zwiazek, J.J., Lieffers, V.J., and Landhäusser, S.M. (2001). Hydraulic conductance in aspen (Populus tremuloides) seedlings exposed to low root temperatures. Tree Physiol. 20, 691-696 https://doi.org/10.1093/treephys/21.10.691.

Way, D.A., and Oren, R. (2010). Differential responses to changes in growth temperature between trees from different functional groups and biomes: a review and synthesis of data. Tree Physiol. 30, 669-688 https://doi.org/10.1093/treephys/tpq015. 